\title{
購買行動と商品陳列方法のベイジアンネットワーク分析 ANALYSIS ON PURCHASE BEHAVIOR ACCORDING TO DISPLAY WAY OF MERCHANDISE BY BAYESIAN NETWORK
}

\author{
立岡恵介*1, 吉田 哲*2, 宗本順三*3 \\ Keisuke TATSUOKA, Tetsu YOSHIDA and Junzo MUNEMOTO
}

\begin{abstract}
By using Bayesian network and Belief propagation, we made relationship clear between display way of merchandise and purchase behavior in mass-market discounter of medium scale shop, selling childhood product after observing and recording customers behaviors. Followings are characteristics of customers" behaviors towards clothes in shelves, displayed by "Face-out", "Sleeve-out" and "Folded". On "Face-out", they tend to act same ways on shelf just after upper one. On "Sleeve-out" and "Folded", they tend to act same way side by side (particularly, on "Folded" they see both sides (they don't tend to pick up or buy them)).
\end{abstract}

Keywords: behavior analysis, purchase behavior, display cases, mass-market discounter, Bayesian Network 行動分析、購買行動、陳列棚、量販店、ベイジアンネットワーク

\section{1 研究の背景、目的}

近年、幹線道路のロードサイドに $300 \sim 1000 \mathrm{~m}^{2}$ の中規模小売店舗 (以下小売量販店）のチェーンストアが立地している ${ }^{1)} 。$ 多くは量 販店であり、同じ規格の陳列棚を格子状に均一の間隔で並べ、様々 な商品が陳列・販売されている。商品の陳列棚、特に洋服の陳列棚 では、フェイスアウト、スリーブアウト、フォールデット等の陳列 方法で商品が陳列されているが、どの高さの陳列棚でいずれの陳列 方法をとると、来店者が購入するかについて、また、購入までのプ ロセスがどのように生じているのかについては、データ取得の難し さもあり、十分に明らかにされていない。陳列方法に応じて異なる 「商品を視認する」「手に取る」「購入する」(以下購買行動）等の一 連の購買行動に基づいた、より効果的な商品陳列が重要である。

また、インターネットでの商品購買が日常的になり、一方で、コ ンピュータの技術革新が進むに従い、大量のデータを高速で処理す る事が可能になるにつれ、商品購買者のプロファイル情報や購買履 歴 (購買商品の嗜好)、ブラウジング履歴などのデータをもとに、パ ーソナライズ化された商品推薦をおこなうことによって、個人によ つて異なる個別の嗜好へのマッチングが技術的に可能となりつつあ る。この商品推薦にはベイジアンネットワークがしばしば用いられ る。ベイジアンネットワークでは、商品の購買を価格や嗜好によっ
て生じる個別の群の生成を条件付確率の連鎖と捉えている。ベイジ アンネットワークは、統計的に「依存関係のある変数の間を向きを 持ったリンクで結び、リンクをたどったパスが循環しないような非 循環有向グラフで表される確率モデル」2)であり、特に商品の購買行 動では、個人によって異なる嗜好を感性情報とし、感性情報に則し

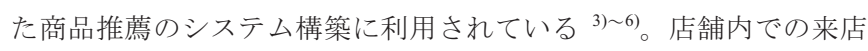
者の購買意思決定に影響を与える店舗内状況要因として、青木は商 品構成要因、人的要因、レイアウト要因(商品配置、陳列形態) を挙 げている7)。このレイアウト要因に関して、1970 年代から用いられ ているインダストリアルエンジニアリング手法（以下 IE 手法）注1) では、動線管理の達成率と売上げを指標とし、来店者と販売員の動 線の効率化を図る商品配置や陳列形態の決定に応用されている ${ }^{8)}$ 。 また、宗本はベイジアンネットワークを行動分析に用い、空間内で の人間行動を捉えて、空間の好みと空間要素の関係を得ている ${ }^{9)}$ 。 Yamaguchi 他はベイジアンネットワークを用いた分析によって、福 岡市の複数の店舗の回遊行動から、待ち合わせのために用いられる 店舗は待ち合わせ以外には用いられないことを明らかにした ${ }^{10)} 。 ま$ た Sato 他は、コンビニエンスストアの来店者の店舗内の移動行動を 来店者の嗜好に基づく商品の選択行動と捉えコンジョイント分析を 行った。この結果をエージェントを用いたモデルに適用し、混雑時

\footnotetext{
本論は, 文献16で発表したものを含む。

*1 ボストンコンサルティンググループ 修士(工学)

*2 京都大学大学院工学研究科 准教授. 博士 (工学)

*3 京都大学大学院工学研究科 教授. 工博
}

THE BOSTON CONSULTING GROUP, Mr. Eng.

Assoc. Prof., Graduate School of Engineering, Kyoto University, Dr. Eng.

Prof., Graduate School of Engineering, Kyoto University, Dr. Eng. 
の店舗内の密集地点の予測に用いてその有効性を検証している ${ }^{11)}$ 。 本論では、陳列棚の前での来店者の「商品を視認する」「手に取る」 「購入する」などの行動の連続の仕方は、例え同じ人・陳列方法で あっても必ずしも常に同じになるとは限らず、これらの行動は、あ る確率で生じる行動の連鎖ととらえることができると考える。つま り、シームレスに連続する来店者の行動を個別の購買行動にあては めて、その連鎖を条件付確率の連鎖として表すことが、来店者の購 買行動の状況をモデルとしてよく表していると考える。このように 一連の購買行動を知ることは、店舗内での来店者の行動を知る上で 重要である。来店者の購買心理や嗜好を取り入れて、購買に至るま でのプロセスをメカニズムとして説明することが本来望ましいモデ ルではあるが、これらのデータを個別の来店者毎に購買行動の生起 する毎に得ることは技術的に困難であるため、本論では、購入に至 るまでの一連の購買行動をデータとして取得し、商品の購買行動の 生起・連鎖する確率を条件付確率の連鎖と捉え、陳列棚の前での来 店者の購買行動と陳列方法との間の関係を明らかにすることを目的 とする。

\section{2 分析の方法}

本論では分析には、入力データを最も良く説明するようにグラフ 構造と条件付確率を決定するべイジアンネットワークを用いる。ベ イジアンネットワークは確率変数、確率変数間の条件付依存関係、 条件付確率の 3 つによって定義されるネットワーク状の確率モデル である 12) 13)。ベイジアンネットワークは項目間相互の依存関係を 有向リンクの矢印によって表現することができるため、関係する項 目すべてのクロス表を比較するよりも、項目間の相互依存関係の理 解が視覚的に容易である(作業過程でクロス表は得られる)。なお、 似た分析手法に共分散構造分析があるが、共分散分析はデータの正 規性が前提とされるため、分析に制限がある。これに対して、ベイ ジアンネットワークでは、個々の確率值を割り当てた不連続な確率 分布によるモデルであるので計算の自由度は高く、線形から非線形 の依存関係にまで柔軟な近似が可能である ${ }^{12)}$ 。また本論文では、項 目間のネットワーク図を得た後に、項目のとる值同士の間での出現 確率の変化までを得る。以上までを得る場合、特に、来店者の行動 予測という不確定要素を含む推論の精度の向上には、各項目の条件 付き確率の連鎖によって表現されるベイジアンネットワークを用い ることが適切である。

文献 12 によれば、ベイジアンネットワークは、確率変数をノー ドとし、変数間の関係を有向リンクで表すグラフ構造を持つ(図 1) 有向リンクの元のノードを親ノード、先にあるノードを子ノードと 呼び、有向リンクによって親から子の向きに関係があることを示す。 子ノード $X_{j}$ に対する複数の親ノードの集合 $P a\left(X_{j}\right)$ と表すと、 $X_{j}$ と $P a(X j)$ の間の関係は、子ノードの変数 $X_{j}$ について親ノードの值を条 件とする条件付確率によって以下のように定量的に表すことができ る。

$$
P\left(X_{j} \mid \operatorname{Pa}\left(X_{j}\right)\right)
$$

さらに $\mathrm{n}$ 個の確率変数 $X I, \cdots, X_{n}$ のそれぞれを子ノードとして同様 に考えると全ての確率変数の同時確率分布は次式のように表せる。

$$
P\left(X_{1}, \cdots, X_{n}\right)=P\left(X_{1} \mid P a\left(X_{1}\right)\right) \cdot P\left(X_{2} \mid P a\left(X_{2}\right)\right) \cdots P\left(X_{\mathrm{n}} \mid P a\left(X_{\mathrm{n}}\right)\right)
$$

$$
=\prod^{n} P\left(X_{j} \mid P a\left(X_{j}\right)\right)
$$

変数間の依存関係は、各子ノードとその親ノード間にリンクを持
つグラフと式(1)の全ての確率值を並べた表、条件付確率表 (CPT) で 定義されるベイジアンネットワークにより、モデル化される。親， ードがある状態 $P a(X j)=X$ （x は親ノード群の各值で構成したベクト ル）のもとでの $\mathrm{n}$ 通りの離散状態 $y 1, \cdots, y_{n}$ を持つ変数 $X_{j}$ の条件付 確率分布は $p\left(X_{j}=y_{1} / X\right), \cdots, p\left(X_{j}=y_{n} / X\right)$ となる。これを各行として 親ノードが取りうる $\mathrm{m}$ 個の全ての状態 $P a(X j)=X 1, \cdots, X m$ のそれぞれ について列を構成し、確率值を定めた表が $X_{j}$ の条件付確率表 (CPT) となる。モデルの構築は、情報量基準注 1) を用いて入力データを最 も良く説明するようにグラフ構造と条件付確率を決定することで行 われる。

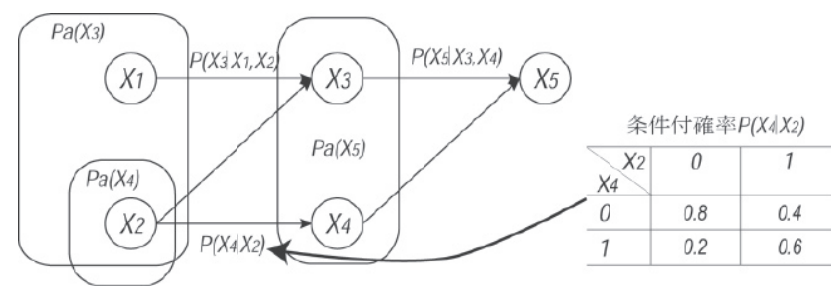

図 1 ベイジアンネットワーク概略図（文献 14 より引用） 本研究では陳列棚の前での来店者の購買行動（視認、手に取る、 購入するなど）を確率変数として購買行動のベイジアンネットワー クを構築し、確率伝搬法注 2) による確率推論を行うことによって陳 列方法の相違による購買行動の特徵を明らかにする。

\section{3 実験の概要}

\section{$3-1$ 陳列棚の設定}

陳列棚は、上下方向に 4 段、左右方向には 3 列となるようにした。 陳列棚上の位置を示寸番地を設定した上で（n1-n12）（図 2)、同じ 番地には同じ商品を陳列し、各番地での陳列方法を換えるよう設定 した。商品の品質の違いによる購買行動への影響を小さくするため に、同価格、かつ同程度の販売量である 12 種類の幼児用長袖シャ ツを陳列する商品として選んだ。また、陳列方法毎に衣類の並べら れる順番も固定した（図 3)。フェイスアウト、スリーブアウト、フ オールデッドの 3 つの陳列方法は図 4 に示寸通りである。これを 1 段毎に同じとなるように組合せ、量販店で一般によく見られる $\mathrm{d} 1-\mathrm{d} 7$ の 7 つの陳列形態を設定し、実験を行った（図 3)。
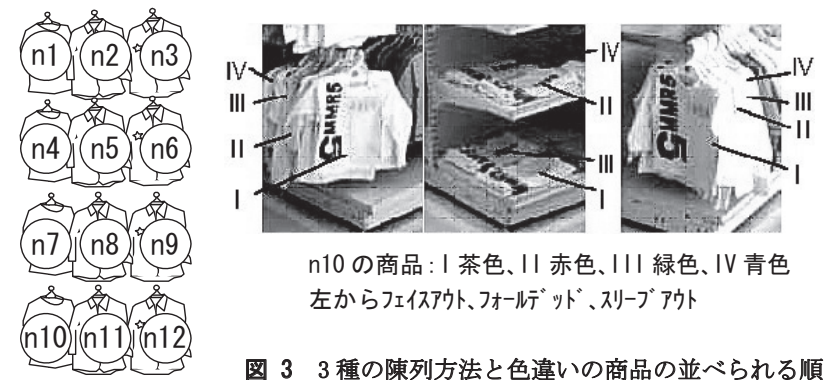

n10 の商品 : I 茶色、II 赤色、 III 緑色、IV 青色 左からフェイスア外、フォールデッド、双ーブ訃

图 33 種の陳列方法と色違いの商品の並べられる順序

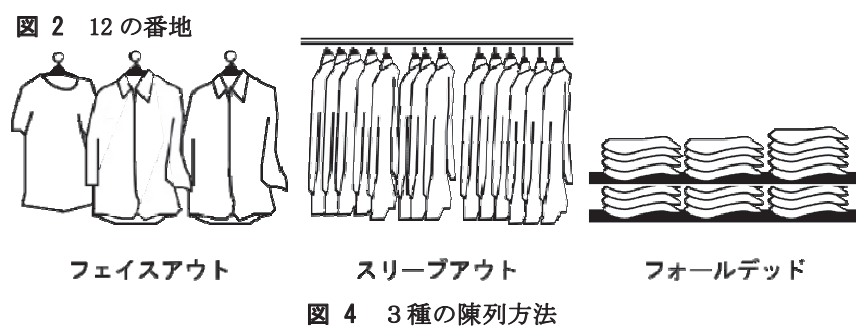




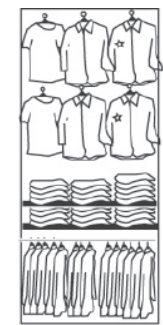

d1

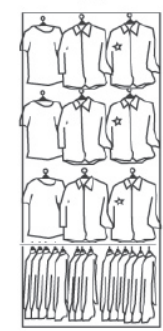

d5

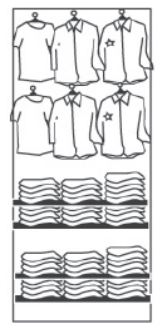

$\mathrm{d} 2$

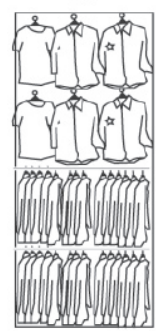

d6

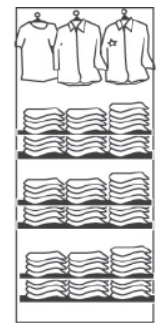

d3

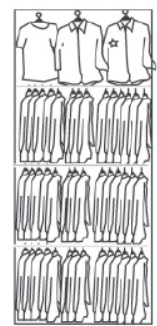

d7

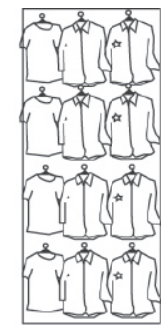

d4 は陳列形態ｄ１-62 名分データを一番手前に置いて示した）。

表 2 陳列形態 $\mathrm{d} 1 \sim \mathrm{d} 7$ の前での行動データ

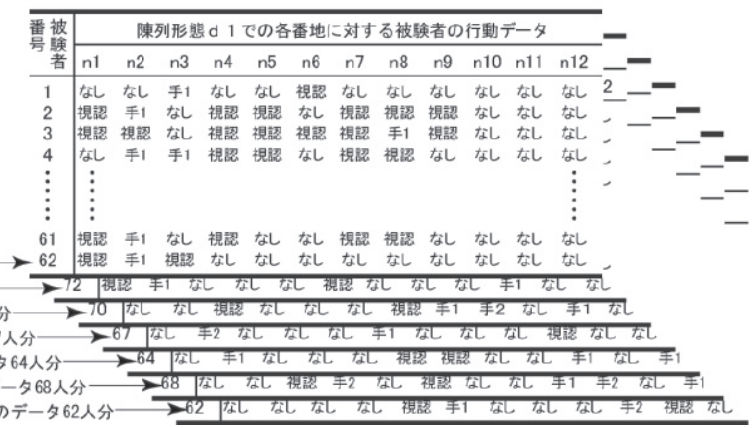

\section{4-2 購買行動のベイジアンネットワーク}

表 2 のデータから 7 陳列形態の各番地の商品への来店者の行動 の関係を示す心゙イジアンネットワークを得た (図 7 次頁)。ベイジア ンネットワークの構築アルゴリズムには WEKA3.4.8 注5)の BayesNet を用いた。各子ノードに最適な局所木の探索 15)、注 6)には、Hill climber を用いた。各ノードは表 1 で設定した各番地での行動に対 応する。ネットワークの信頼度は、各ネットワークで視認回数が多 かった番地で来店者の行動の各離散值の判別率で示した。この結果、 表 3 に挙げるようにア〜エの 3 つの特徵的な行動の連鎖が得られた。 上下に並ぶフェイスアウトでは上下に同じ行動が連続する（上段で 視認されれば下段でも視認、上段で商品を 1 枚手に取れば下段でも 商品を 1 枚手に取る、など、有向リンクの方向と同じ方向に同じ行 動となる）ことが多く（ア）、左右に並ぶスリーブアウトは左右に同 じ行動が連続する (右の商品で視認されればその左でも視認される、 など有向リンクの方向と同じ方向に同じ行動となる）ことが多い (イ)。また、フェイスアウトとスリーブアウトが上下に並ぶ場合に は上下で同じ行動が連続することが多く（ウ）、左右に並ぶフォール デッドでは左右に同じ行動が連続することが多い (エ)。

表 3 陳列形態 $\mathrm{d} 1 \sim \mathrm{d} 7$ の前での特徴的な行動の連鎖

\begin{tabular}{l|l|l}
\hline ア & フェイスアウト & 上下で同じ行動を取りやすい \\
イ & スリーブアウト & 左右で同じ行動を取りやすい \\
ウ & フェイスアウト (上段) & 上下で同じ行動をりや取りすい \\
& +スリーブアウト (下段) & \\
エ & フォールデッド & 左右で同じ行動（視認）をを取りやすい \\
\hline
\end{tabular}

\section{4-37 陳列形態での購買行動}

各陳列形態での来店者の滞留行動を確率伝搬法を用いて分析し、 出入口

図 6 実験対象の陳列棚と web カメラの位置

\section{4 来店者の購買行動のモデル化}

\section{4-1 来店者の購買行動の種類}

各番地の商品に対する来店者の行動を、商品に対する視認・1 枚 手に取る・2 枚手に取る・購入に分類し、表 1 のように記録した。

表 1 各番地の商品に対する行動 $\mathrm{nX}$ は各番地

\begin{tabular}{|c|c|c|c|c|c|}
\hline 行動の種類 & なし & 視認 & 1 枚手に取る & 2 枚以上手に取る & 購入 \\
\hline 略記号 & nXーなし & $n X$-視認 & $n X-$ 手 1 & $n X-$ 手 2 & $n X$-購入 \\
\hline
\end{tabular}

設定した各番地の行動を列、各陳列形態毎に $\mathrm{m}$ 人 (d1-62人、 $\mathrm{d} 2-72$ 人、 $\mathrm{d} 3-70$ 人、 $\mathrm{d} 4-67$ 人、 $\mathrm{d} 5-64$ 人、 $\mathrm{d} 6-68$ 人、 $\mathrm{d} 7-62$ 人) を行とする $\mathrm{m}$ 行 13 列（被験者の id を 1 列目に振った）の行列を得た。各陳列 形態につき入力データ行列を作成し、7つの行列を作成した（表 2 陳列されている番地毎の商品に対する来店者の行動を調べた。d5 の 陳列形態を例に述べる（図 8)。確率伝搬法のアルゴリズムには、 BayoNet4.0 注 7)の MSSM を用いた。
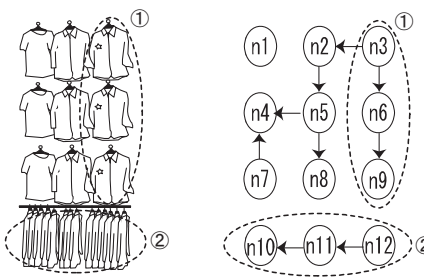

(n10) n11) (n12);

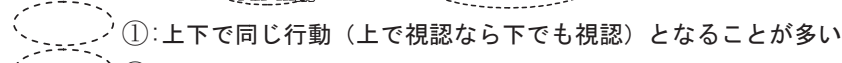
…… (2):左右で同じ行動（右で視認なら左でも視認）となることが多い 図 8 d 5 での行動の関係

フェイスアウト陳列の $\mathrm{n} 4$ と $\mathrm{n} 7 、 \mathrm{n} 2$ と $\mathrm{n} 5$ と $\mathrm{n} 8 、 \mathrm{n} 3$ と $\mathrm{n} 6$ と $\mathrm{n} 9$ は それぞれ有向リンク（図 8 中 $\rightarrow)$ があり、このリンクの方向に従っ 


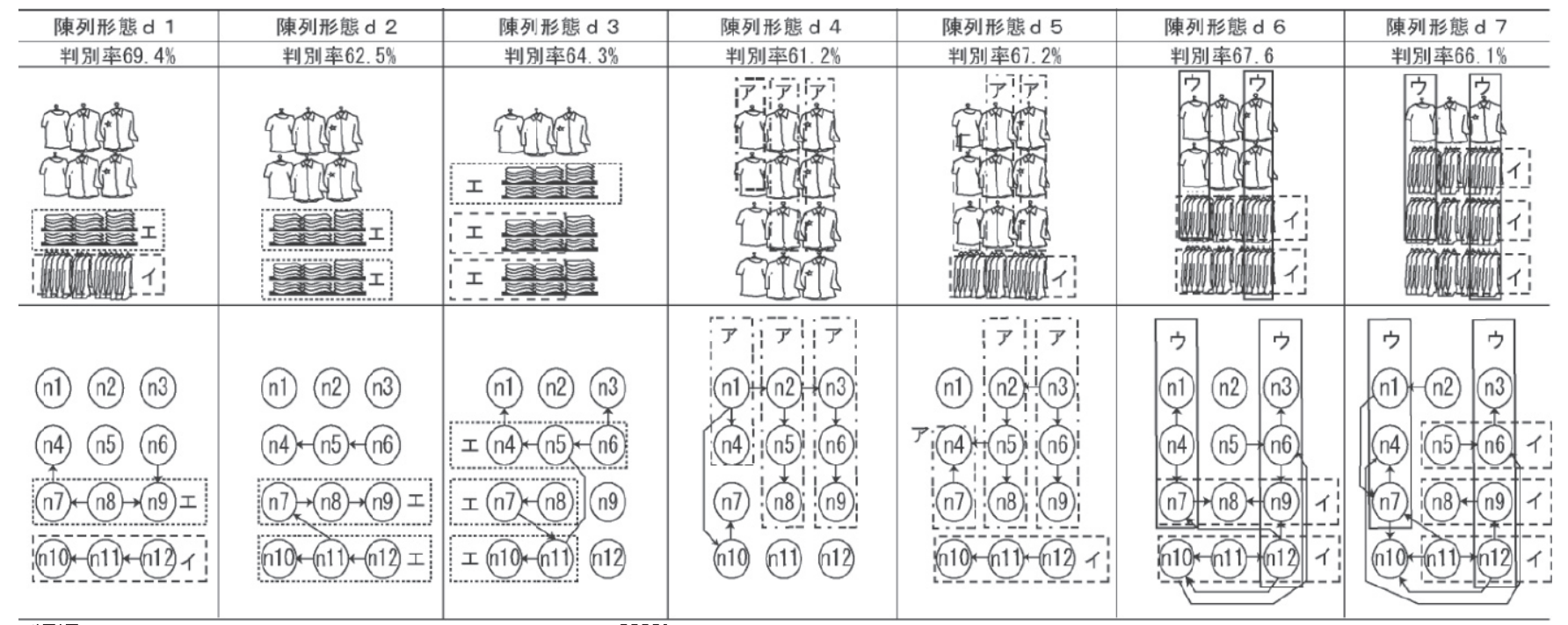

予：フェイスアウト：上下で同じ行動をとりやすい

ウ：フェイスアウト:スリーブアウト、上下で同じ行動をとりやすい: エ: : フォールデッド : 左右で同じ行動（視認）をとりやすい

\section{図 7 各番地の商品に対する行動の関係を表すベイジアンネットワークと陳列形態}

て行動が生じていることが多いことがわかった。入口すぐの棚で、 来店者は入口を入って壁に沿って店の奥方向へ移動するためか棚の 右上の番地 $\mathrm{n} 3$ の商品が起点となっていた。

リンクの両端部での商品に対する行動が生じる確率を n3 の商品 に対する行動を証拠条件として確率伝搬法により求めたものを例に 示す (表 3)。表中の数值は、表上部ではn3（表中行方向）で各々の

表 $3 \mathrm{n} 3$ での行動（表中行方向）とn2、n6 での行動（表中列方向）の関係

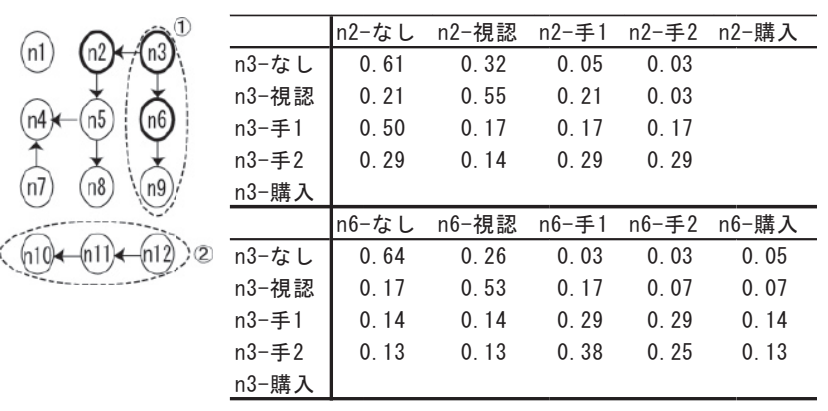

なし：行動なし、手 $1:$ 商品 1 種を手に取る、手 $2:$ 同 2 種

行動をした後に n2（表中列方向）での行動の条件付き確率を、表下部 では n3（表中行方向）の後の n6（表中列方向）の行動となる条件付 き確率を表している。観察中生じなかった行動については表内の数字 も空闌となっている。n2、n3 の商品についてはn 3 の商品で行動なし （n3-なし）、n3 の商品を視認寸る場合 (n3-視認)、それぞれで n2なし、n2-視認が大きな值を示しており、n3 視認した場合にはn2の 視認が生じる確率が高くなる。n3、n6 については、n3 の商品で行動 なしの場合（n3-なし）にはn6の商品も行動なし（n6-なし）の確率 は 0.64 と高く、n3 の商品を視認する場合（n3-視認）にはn6 の商品 を視認する (n6-視認) 確率が 0.53 と高い。n6 の商品を手に取る (n6手 1）確率は、n3 の商品に対する行動が、行動なし、視認する、商 品を 1 種手に取るとなるにつれて、 $0.03 \rightarrow 0.17 \rightarrow 0.29$ と高くなってい る。n $\mathrm{n}$ と $\mathrm{n} 9$ の番地の商品の間にも同様の関係があったが、両者の 間に $\mathrm{n} 6$ を挟んでいることもあり、n3 と n6 の商品の間での行動ほど その関係は大きくはなかった。

最下段のスリーブアウト陳列の 3 商品への行動（d10,d11,d12）間
にも有向リンク（図 8 中 n 12 からの矢印 $\rightarrow$ ) があり、このリンクの 方向に従って行動が生じることが多いことがわかった。また、上 3 段のフェイスアウト陳列の商品に対する行動との関係はないことが わかる。リンクの両端部での商品に対する行動が生じる確率を $\mathrm{n} 12$ の商品への行動を証拠条件として確率伝搬法により求めたものを例 に示す（表 4）。n12（表中行方向）の商品で行動なしの場合（n12-

表 $4 \mathrm{n} 12$ での行動（表中行方向）とn11 での行動（表中列方向）の関係

(n1) (n2) n3) (1) \begin{tabular}{l|l|l} 
n11-なし n11-視認 n11-手1 n11-手2 n11-購入 \\
\cline { 2 - 4 }
\end{tabular}

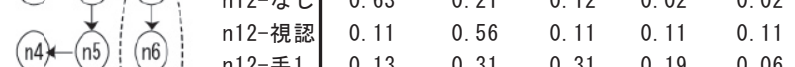
(17) $\quad n 12$-手 $1 \quad \begin{array}{lllll}0.13 & 0.31 & 0.31 & 0.19 & 0.06\end{array}$ (n7) (n8) $\begin{array}{lllllll}n \text { ng } ; & \mathrm{n} 12-\text { 手2 } & 0.14 & 0.14 & 0.14 & 0.14 & 0.43 \\ \mathrm{n} 12 \text { 購入 } & & & & & \end{array}$ (110) (111) (102) : 2 : 行動なし、手 $1:$ 商品 1 種を手に取る、手 $2:$ 同 2 種 なし）には、n11の商品でも行動なし（n11-なし）が 0.63、n12の商 品を視認する場合（n12-視認）には、n11 の商品を視認する（n11視認）確率が 0.56、n12 の商品を 1 種手に取る場合（n12-手 1) には $\mathrm{n} 11$ の商品を 1 種手に取る (n11-手 1 ) 確率が 0.31 と他と比較して高 くなっていた。

d5 での行動の特徵をまとめると

1) フェイスアウト陳列では、上下の商品を上から順に視認する、 もしくは手に取るという行動が見られる。

2 ）最上段のフェイスアウト陳列の商品で、特に最も右から左へ視 認の有無の行動が同じになる。

3 ）最下段のスリーブアウト陳列では、上段のフェイスアウト陳列 の商品に対する行動とは関係がない。また、隣の商品に対する行動 と同じ行動をとる。

以上の分析を $\mathrm{d} 1$ 〜 $\mathrm{d} 7$ のすべての陳列形態に対して行い、その結果 から、同じ陳列方法で共通した行動を示している点を表 5 のように まとめ、下記ア）～エエ）のように陳列形態に共通するルールを抽出 した（ア〜エは表 3、図 7 中ア〜エと対応している）。なお、d5 での 行動で得た上節の知見は表 5 中、d5-1、d5-2、d5-3 と示寸。 
表 5 d 1 d 7 の陳列形態で見られる行動の特徽

\begin{tabular}{|c|c|c|c|c|c|c|c|c|c|}
\hline \multirow{2}{*}{$\begin{array}{l}\text { 陳列 } \\
\text { 形態 }\end{array}$} & \multicolumn{4}{|c|}{ 行動の起点 } & \multicolumn{5}{|c|}{ 左記の行動に引き続き起こりやすい行動 } \\
\hline & 段位置 & 列位置 & 陳列法 & 行動 & 段位置 & 列位置 & \begin{tabular}{|c|} 
陳列法 \\
\end{tabular} & 行動 & 図 7 中記号 \\
\hline \multirow{3}{*}{ d1 } & 下 2 & 中央 & フォールデッド & 指定無 & 下 2 & 両端 & フォールデッド & 起点と同行動 & $I$ \\
\hline & 下 2 & 両端 & フォールデッド & 指定無 & 上 2 & 当該上 & フェイスアウト & 起点と同行動 & \\
\hline & 最下 & 右端 & スリーブアウト & 指定無 & 最下 & 起点の隣 & スリーブアウト & 起点と同行動 & 1 \\
\hline \multirow{3}{*}{ d2 } & 下 2 & 指定無 & フォールデッド & 視認 & 下 2 & 指定無 & フォールデッド & 起点と同行動 & $\bar{I}$ \\
\hline & 上 2 & 左端 & フェイスアウト & 指定無 & 上 2 & 中央 & フェイスアウト & 起点と同行動 & \\
\hline & 最下 & 右端 & フォールデッド & 視認 & 最下 & 中央 & フォールデッド & 起点と同行動 & $I$ \\
\hline \multirow{2}{*}{ d3 } & 上 $2 、$ 下 2 & 指定無 & フォールデッド & 視認 & 同段 & 指定無 & フォールデッド & 起点と同行動 & $I$ \\
\hline & 上 2 & 右端 & フォールデッド & 指定無 & 一段上 & 当該上下 & フェイスアウト & 起点と同行動 & ウ \\
\hline \multirow{3}{*}{ d4 } & 最上 & 指定無 & フェイスアウト & $\begin{array}{l}\text { 視認、手 1、 } \\
\text { 手 } 2\end{array}$ & 一段下 & 当該同列 & フェイスアウト & 起点と同行動 & $\boldsymbol{P}$ \\
\hline & 最上 & 指定無 & フェイスアウト & 視認 & 最上 & 指定無 & フェイスアウト & 起点と同行動 & \\
\hline & 最上、上 2 & 中央 & フェイスアウト & 視認 & 一段下 & 中央 & フェイスアウト & 起点と同行動 & $\boldsymbol{P}$ \\
\hline \multirow{3}{*}{ d5 } & $d 5-1)$ 最上、上 2 & 指定無 & フェイスアウト & \begin{tabular}{|l} 
視認、手 1、 \\
手 2
\end{tabular} & 一段下 & 当該同列 & フェイスアウト & 起点と同行動 & $\boldsymbol{P}$ \\
\hline & d5-2)最上 & 指定無 & フェイスアウト & 視認 & 最上 & 指定無 & フェイスアウト & 起点と同行動 & \\
\hline & $d 5-3)$ 最下 & 指定無 & スリーブアウト & 指定無 & 同段 & 起点の隣 & スリーブアウト & 起点と同行動 & 1 \\
\hline \multirow{3}{*}{ d6 } & 下 2、最下 & 指定無 & スリーブアウト & 指定無 & 同段 & 指定無 & スリーブアウト & 手 1、手 2 & \\
\hline & 上 $2 、 下 ~ 2$ & 両端 & \begin{tabular}{|l} 
フェイスアウト、 \\
スリーブアウト
\end{tabular} & 視認 & 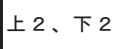 & 当該同列 & $\begin{array}{l}\text { フェイスアウト、 } \\
\text { スリーブアウト }\end{array}$ & 手 1、手 2 & ウ \\
\hline & 上 2 & 左端 & フェイスアウト & 手 1 & 最上 & 左端 & フェイスアウト & 手 1 & $\bar{P}$ \\
\hline \multirow[b]{2}{*}{ d7 } & 上2、下 $2 、$ 最下 & 中央 & スリーブアウト & 指定無 & 同段 & 右端 & スリーブアウト & 起点と同行動 & 1 \\
\hline & 全段 & 両端 & $\begin{array}{l}\text { フェイスアウト、 } \\
\text { スリーブアウト }\end{array}$ & 指定無 & 他の段 & 同列 & $\begin{array}{l}\text { フェイスアウト } \\
\text { スリーブアウト }\end{array}$ & 起点と同行動 & ウ \\
\hline
\end{tabular}

以上 $\mathrm{d} 1$ から $\mathrm{d} 7$ の分析から得られた知見を以下にまとめる。

ア）フェイスアウト陳列が多い場合（ $\mathrm{d} 4, \mathrm{~d} 5)$ には、フェイスアウト 陳列の上下の商品に対して同じ行動をとりや寸い。d4 については行 動なし、視認、1 枚以上手に取るについて同じ行動をとる確率が相 対的に 0.1 以上高く、d 5 については 0.25 以上高かった。

イ）スリーブアウト陳列（ $\mathrm{d} 1, \mathrm{~d} 5, \mathrm{~d} 7)$ では、左右の商品に対して同じ 行動をとりやすい。特に $\mathrm{d} 1$ の最下段では左右の商品に対して行動な し、視認、1 枚以上手に取る行動について同じ行動をとる確率が他 の行動と比較して 0.25 以上高い。 $\mathrm{d} 5$ については行動なし、視認につ いて同じ行動をとる確率が 0.25 以上高くなっており、手に取るにつ いても他の行動と比較して確率の差は小さいが同じ行動をとりやす いことがわかった。

ウ）スリーブアウト陳列が多い陳列棚の両端の商品については側方 から見るとフェイスアウト陳列に見えるためか、上下の商品に対し て同じ行動をとりやすいという関係がみられた（d6,d7）。d7 のスリ ーブアウト陳列の上下の商品について行動なし、視認、1 枚手に取 るについて同じ行動をとる確率が最高となることがわかった。特に 行動なし、1 枚手に取るについては他の行動と比較して 0.12 以上高 くなっており、これら 2 つの行動についての関係が大きいことがわ かった。

エ）フォールデッド陳列（ $\mathrm{d} 1, \mathrm{~d} 2, \mathrm{~d} 3)$ では、特に左右の商品の視認の 有無に関係が見られた。これは、フォールデッド陳列では商品の表 と色のバリエーションを同時に見ることができるため、来店者は商 品の情報を視認のみで得ることができるからと考えられる。下から 2 段目のフォールデッド陳列 $(\mathrm{d} 1, \mathrm{~d} 2)$ の場合には、行動なし、視認、 1 枚以上手に取るにおいて左右の商品と同じ行動をとる確率が他の 行動と比較して、0.08 と僅かではあるが高くなっている。また、上 から 2 段目（d3）では左右の商品の視認の有無についてのみ、同じ 行動をとる確率が他の行動と比較して 0.14 以上高くなった。

\section{5 まとめ}

本論では小売店舗内での消費者の購買行動を観察し、1 陳列棚内 での商品の陳列方法と購買行動の関係を、ベイジアンネットワーク と確率伝搬法によって以下のように明らかにした。
フェイスアウト、スリーブアウト、フォールデッドの 3 つの陳列方 法の商品に対する来店者の行動の特徴は、

・フェイスアウト陳列：上下の商品

・スリーブアウト陳列 : 左右の商品

・フォールデッド陳列：左右の商品に対して視認のみ

に対して同じ行動をとりやすいことがわかった。以上の結果より、 陳列棚の作成において、

・スリーブアウト陳列を用いる場合には、左右の商品に対して同じ 行動をとる傾向があるため、よく売れる商品と売りたい商品を左右 に陳列すると視認や手に取るなどを誘導しやすい。

・陳列棚の両端にスリーブアウト陳列を用いる場合には上下の商品 に対して同じ行動をとる傾向があることから、上下によく売れる商 品と売りたい商品を陳列すると視認や手に取るなどを誘導しやすい。 ・スリーブアウト陳列が多い陳列形態では確率モデルのグラフ構造 が複雑になり、来店者の行動の予測が困難であった。これは、スリ ーブアウト陳列は商品の袖しか見せることができないため来店者の 視線が定まらず、購買行動に個人差が生じたと考えられる。

・フェイスアウト陳列を多く用いる場合には、上下の商品に対して 同じ行動をとる傾向があるため、よく売れる商品と売りたい商品を 上下に陳列することによって来店者は自然に、関連商品を視認し、 手に取り、購入することができる。

・フォールデッド陳列を用いる場合には、左右の商品に対して、特 に視認の有無に共通する関係があった。フォールデッド陳列では来 店者は左右の商品を視認しやすく、よく売れる商品と売りたい商品 を左右に陳列することでと視認や手に取るなどを誘導しやすい。こ れは、フォールデッド陳列では商品の表と色のバリエーションを同 時に見ることができ、視認のみで商品の情報を多く得ることができ るためと考えられる。以上、陳列形態毎の来店者の購買行動の特徴 を抽出することができた。

本論の調査にあたって、株式会社西松屋チェーンの皆様に多くの御助力、ま た、貴重なご助言を頂きました。記して謝意を表します。 
注

注 1) モデル選択の基準となる統計量で期待対数尤度からの近似アプローチに よって得られる赤池の情報量基準(AIC)を用いた。AICでは、推定されたモデ ル分布と真の分布との間のカルバック・ライプラー情報量を最小化して得る 13)

注 2)任意の対象（変数 X) のとる離散值が出現する確率值（事後確率と呼ばれ る）を求めるために、変数間の局所計算を繰り返しながら確率をネットワー ク中に伝搬することによって、各変数の確率分布を更新していく計算法 ${ }^{12)}$ 。

注 3)フェイスアウト、スリーブアウト、フォールデッドが $\mathrm{d} 1$ ～d7 の実験の中で 存在する平均縦段数が各及、 $15 / 7 \doteqdot 2.14,7 / 4=1.75,6 / 3=2$ となり、等しくない。 実験の実施上、来店者への暴露平均緹段数が同値になるように各陳列方法に 重み付けをした実験となっていなかった。このためフェイスアウトでは上下 に同一の行動を採るようなバイアスがかかっていたことは否定できない。

注 4) 西松屋向日店（京都府向日市）

注 5) ニュージーランドのワイカト大学の Ianh. Witten, Eibe. Frank を中心として JAVA で開発されたオープンソースのデータマイニングツールで世界中の研 究者が利用している。

注 6)す心゙ての変数の取り得るグラフ構造の組合せは変数が増加する毎に爆発的 に多くなる。これをすべて探索するのは探索空間が広大になりすぎるため、 仮説として候補を限定し様々な条件の下でデータフィッティングを行いなが ら全体のネットワークを得ることが望ましい。子ノードを根、これに接続す る親ノード群を葉とした 1 組の木（これを局所木と呼ぶ）に着目すると、心゙ イジアンネットワークはこの木が組合わさったものであり、この局所木に 1 つ条件付確率分布が定義される。局所木の探索によって各子ノード毎に最適 な局所木を得、これを繰り返すことで全体のネットワークを構築する作業 15) 。

注 7) 産業技術総合研究所で本村陽一を中心に 2001 年に開発されたベイジアン ネットワークのソフトウェア ${ }^{13)}$ 。SQL データベースに格納された大量のデ 一タとのインターフェイスが可能で、グラフ構造の探索機脳など様々な機能 が追加されている。SQL データベースでデータベースを作成するので、デー 夕をメモリに読み込むことなく作業が害行できるためデータ量の増加に対し て計算速度の低下を起こさない利点がある。本論では、wekaで得たネットワ ークで結ばれた項目相互間の確率伝搬の計算に用いた。

\section{参考文献}

1)渥美俊一、「ェーンストア経営の目的と現状[新訂版] 、実務教育出版、2004.6 2)本村陽一、ベイジアンネットワーク、電子情報通信学会誌、vol.83、No.8、 pp.645-646、2000.8

3)矢野絵美、北野有亮、末吉恵美、篠原勲、ピンヤポン・シニーナット、加藤俊 一、「消費者の感性モデルを利用したレコメンデーションシステムの構築」、 情報処理学会論文誌、vol.44、No.SIG8(TOD18)、pp.46-54、2003

5)岩崎弘利、水野伸洋、原孝介、本村陽一、「ユーザーの好みに合わせてコンテ ンツを推薦するカーナビへのベイジアンネットの適用」、電子情報通信学会技 術研究報告、NC2004-55、pp.25-30、2004.7

6)村上知子、酢山明弘、折原良平、「ベイジアンネットワークによる消費者行動 分析 一消費者の内部状態の解明に向けて-」、電子情報通信学会技術研究報告、 NC2004-70、pp.9-14、2004.10

7)青木幸広、田島義弘、「店頭研究と消費者行動分析」、誠文堂新光社、 pp.86-89、1989.4

8)渥美俊一、「店舗レイアウト[新訂版]-チェーンストアの実務原則・シリーズー」、 実務教育出版、2003.11

9)宗本晋作、「ベイジアンネットワークを用いた空間嘹好の確率モデルの研究」、 日本建築学会計画系論文集、第 618 号、pp.173-179、2007.8

10)Rui YAMAGUCHI, Saburo SAITO, "Bayesian Networks for Probabilistic Inference of Complex Consumer Shop-around Behavior", Studies in Regional Science, Vol. 37 (2007), No. 3 pp.769-785

11) Sato,H. Kubo,M., Namatame,A., "Simulating customers in a convenience store", Proc of 11th Asia-Pacific Workshop on. Intelligent and Evolutionary Systems (IES), 2007.

12)本村陽一、岩崎弘利、「ベイジアンネットワーク技術 - ユーザー・顧客のモ デル化と不確実性推論 -」、東京電機大学出版局、2006.7
13)繁栘算男、本村陽一、植野真臣、「ベイジアンネットワーク概説」、培風館、 2006.7

14)本村陽、「[特別講演 ベイジアンネットによるヒューマンモデリングの実際」、電子情 報通信学会、信学技報、TECHNICALREPORT OF IEICE, NC2004-54 (2007-7)、pp.19-24

15)本村陽一、「ベイジアンネット構築システム BAYONET」、人工知能学会 基 礎論研究会、2001 年ベイジアンネットチュートリアル、東京、2001.7

16）於芯、立岡恵介、宗本順三、吉田 哲、益田英明、「1 陳列棚での陳列形 態と購買行動の関係一子供用量販店における購買行動の研究 その $2-」 、$ 日本建築学会大会学術講演梗概集（九州）、E-1 分冊、p.1135-1136、2007.8

(2008年 5 月 9 日原稿受理, 2008 年 8 月 4 日採用決定) 